\title{
Sesamoids in Caudata and Gymnophiona (Lissamphibia): absences and evidence
}

\author{
Maria Laura Ponssa ${ }^{\text {Corresp., } 1}$, Virginia Abdala ${ }^{2}$ \\ 1 Área Herpetología, Unidad Ejecutora Lillo (UEL). CONICET-Fundación Miguel Lillo, San Miguel de Tucumán, Tucumán, Argentina \\ 2 Instituto de Biodiversidad Neotropical (IBN), UNT-CONICET. Catedra de Biología General, Facultad de Ciencias Naturales e IML, UNT, Yerba Buena, \\ Tucuman, Argentina \\ Corresponding Author: Maria Laura Ponssa \\ Email address: mlponssa@hotmail.com
}

An integrative definition of sesamoid bones has been recently proposed, highlighting their relationship with tendons and ligaments, their genetic origin, the influence of epigenetic stimuli on their development, and their variable tissue composition. Sesamoid bones occur mainly associated with a large number of mobile joints in vertebrates, most commonly in the postcranium. Here, we present a survey of the distribution pattern of sesamoids in 256 taxa of Caudata and Gymnophiona, and 24 taxa of temnospondyls and lepospondyls, based on dissections, high-resolution X-ray computed tomography from digital databases, and literature data. These groups have a pivotal role in the interpretation of the evolution of sesamoids in Lissamphibia and tetrapods in general. Our main goals were: 1) to contribute to the knowledge of the comparative anatomy of sesamoids in Lissamphibia; 2) to assess the evolutionary history of selected sesamoids. We formally studied the evolution of the observed sesamoids by optimizing them in the most accepted phylogeny of the group. We identified only three bony or cartilaginous sesamoids in Caudata: the mandibular sesamoid, which is adjacent to the jaw articulation; one located on the mandibular symphysis; and one located in the posterior end of the maxilla. We did not observe any cartilaginous or osseous sesamoid in Gymnophiona. Mapping analyses of the sesamoid dataset of urodeles onto the phylogeny revealed that the very conspicuous sesamoid in the mandibular symphysis of Necturus beyeri and Amphiuma tridactylum is an independent acquisition of these taxa. On the contrary, the sesamoid located between the maxilla and the lower jaw is a new synapomorphy that supports the node of Hydromantes platycephalus and Karsenia coreana. The absence of a mandibular sesamoid is plesiomorphic to Caudata, whereas it is convergent in 7 different families. The absence of postcranial sesamoids in salamanders might reveal a paedomorphic pattern that would be visible in their limb joints. 


\title{
Sesamoids in Caudata and Gymnophiona (Lissamphibia): absences and evidence
}

\author{
María Laura Ponssa ${ }^{1 *}$ Virginia Abdala ${ }^{2}$
}

1*Área Herpetología, Unidad Ejecutora Lillo (UEL), CONICET-Fundación Miguel Lillo. Miguel Lillo 251, San Miguel de Tucumán, Argentina. E-mail: mlponssa@hotmail.com.

${ }^{2}$ Instituto de Biodiversidad Neotropical (IBN), UNT-CONICET, Horco Molle s/n, Yerba Buena Argentina. Cátedra de Biología General, Facultad de Cs. Naturales e IML. UNT.

\begin{abstract}
An integrative definition of sesamoid bones has been recently proposed, highlighting their relationship with tendons and ligaments, their genetic origin, the influence of epigenetic stimuli on their development, and their variable tissue composition. Sesamoid bones occur mainly associated with a large number of mobile joints in vertebrates, most commonly in the postcranium. Here, we present a survey of the distribution pattern of sesamoids in 256 taxa of Caudata and Gymnophiona, and 24 taxa of temnospondyls and lepospondyls, based on dissections, high-resolution X-ray computed tomography from digital databases, and literature data. These groups have a pivotal role in the interpretation of the evolution of sesamoids in Lissamphibia and tetrapods in general. Our main goals were: 1) to contribute to the knowledge of the comparative anatomy of sesamoids in Lissamphibia; 2) to assess the evolutionary history of selected sesamoids. We formally studied the evolution of the observed sesamoids by optimizing them in the most accepted phylogeny of the group. We identified only three bony or cartilaginous sesamoids in Caudata: the mandibular sesamoid, which is adjacent to the jaw articulation; one located on the mandibular symphysis; and one located in the posterior end of the maxilla. We did not observe any cartilaginous or osseous sesamoid in Gymnophiona.
\end{abstract}


Mapping analyses of the sesamoid dataset of urodeles onto the phylogeny revealed that the very conspicuous sesamoid in the mandibular symphysis of Necturus beyeri and Amphiuma tridactylum is an independent acquisition of these taxa. On the contrary, the sesamoid located between the maxilla and the lower jaw is a new synapomorphy that supports the node of Hydromantes platycephalus and Karsenia coreana. The absence of a mandibular sesamoid is plesiomorphic to Caudata, whereas it is convergent in 7 different families. The absence of postcranial sesamoids in salamanders might reveal a paedomorphic pattern that would be visible in their limb joints.

Keywords heterotopic elements, amphibians, homology, mandibular sesamoids, tetrapods

\section{Introduction}

In a recent review, sesamoids were defined as "periarticular skeletal elements, which initially form in juxtaposition to or independently of bones and joints. They are commonly related to tendons and ligaments, have a genetic basis and, once they are formed, epigenetic stimuli drive their growth and development to the acquisition of their definitive tissue composition, which can be diverse, for example, cartilage, fibrocartilage, or bone" (Abdala et al., 2019). This definition intends to summarize all the skeletal elements considered as sesamoids in the different groups of tetrapods into one description. The definition is quite broad, because sesamoids are associated with diverse functions, such as the mechanical stress exerted on tendons as they wrap around a bony edge or a joint. This stress might improve tendon ability to react to compressive load, pressure, tensile strain, or vibration (Pearson \& Davin, 1921ab; Carlsöö, 1982; Nussbaum, 1982; Sarin et al., 1999; Benjamin \& Ralph, 1998; Jerez et al. 2010; Ponssa et al., 2010; Tsai \& Holliday, 2011; Otero \& Hoyos, 2013; Regnault et al., 2016; Abdala et al., 2017; Zhang et al., 
2017). Moreover, sesamoids are described in all the large vertebrate groups (Abdala et al., 2019). They occur mainly associated with a large number of mobile joints, most commonly in the postcranium (e.g., Romankowowa, 1961; Vickaryous \& Olson, 2007; Ponssa et al., 2010; Jerez et al., 2010; Chadwick et al., 2014; Regnault et al., 2014; Reyes-Amaya et al., 2017; Samuels et al., 2017; Denyer et al., 2020), and in the skull of some taxa (e. g., Hofling \& Gasc, 1984; Tsai \& Holliday, 2011; Montero et al., 2017). The number of cranial sesamoids is notoriously higher in Osteichthyes than in tetrapods (Alexander, 1967; Adriaens \& Verraes, 1998; Diogo et al., 2001; Summers et al., 2003; Datovo \& Bockmann, 2010), possibly due to the higher number of mobile joints in the fish skull (Iordansky, 1989; Montero et al., 2017; Abdala et al., 2019).

More than 20 types of osseous, cartilaginous or fibrocartilaginous sesamoids have been described in amphibians (Laurent, 1961; Nussbaum, 1982; Olson, 2000; Hoyos, 2003; Guayasamin, 2004; Avilan \& Hoyos, 2006; Fabrezi, 2006; Ponssa et al., 2010; Abdala et al., 2017), most of them in 33 extant families of anurans (Ponssa et al., 2010). The earliest records of sesamoids in amphibians include an oval bone lying next to the radial, and distal to the ulnar portion of the radio-ulna in Xenopus arabiensis from the Upper Oligocene (Henrici \& Báez, 2001). This element is located on the dorsal surface of the carpus in the same position as in other Xenopus species (Henrici \& Báez, 2001). A sesamoid behind the diapophysis, beneath the iliac shaft, was identified in a juvenile anuran from the Lower Cretaceous Jiufotang Formation (Wang et al., 2007).

The skeletal anatomy of Caudata and Gymnphiona has been extensively studied (e.g., Wake, 1963; Bemis et al., 1983; Wake et al., 1983; Restrepo, 1995; Shubin, 1995; Müller, 2006; Schaah, 2010; Wu et al., 2012; Villa et al., 2014; Jia et al., 2018; Cala et al., 2019; Khoshnamvand et al., 2019; Bardua et al., 2019; Marshall et al., 2019; Macaluso et al., 2020). 
Nevertheless, no work has focused on their sesamoids. This gap of knowledge has attracted our attention, since the Caudata group has a pivotal role in the interpretation of the evolution of sesamoids in tetrapods. Likewise, Gymnophiona cannot be ignored if the evolution of sesamoid in amphibians is to be unveiled.

In Caudata, only a cranial sesamoid in the squamosal-collumelar ligament was mentioned (Nussbaum, 1982), with no data or information about the species having been published. Interestingly, cranial sesamoids have been rarely recorded among tetrapods (Bramble, 1974; Tsai \& Holliday, 2011; Montero et al., 2017; Abdala et al., 2019). The sesamoids located in the cranium of tetrapod amniotes include the transilient cartilage or bone in the bodenaponeurosis of the jaw adductor muscles in crocodiles and turtles (Iordansky, 1964; Schumacher, 1973; Holliday \& Witmer, 2007; Tsai \& Holliday, 2011); elements in the basipterygoid and pterygoid bones in some squamates (Gauthier et al., 2012); the quadrate element in Ophiodes; the X element in amphisbaenians (Montero et al., 2017); a small bone strengthening the external jugomandibular ligament in its retro-articular portion in Rhamphastos (Hofling \& Gasc, 1984); and the controversial Paaw cartilage in marsupial mammals (Sánchez-Villagra et al., 2002). The only records of cranial sesamoids in anuran amphibians belong to Barbourula busuangensis (Clarke, 1987; Roček et al., 2016) and Chacophrys pierotti (Fabrezi et al., 2017). Considering these data, the report of the sesamoid in the columellar squamous ligament of Caudata is striking, given the notable scarcity of sesamoid records in this area for the entire tetrapod clade. In Gymnophiona, sesamoids are unknown. Data scarcity on sesamoid occurrence in Caudata and Gymnophiona draws our attention, because osteology is considered in several ongoing projects about the morphology of these taxa (Bemis et al., 1983; Muller, 2006; Villa et al., 2014; Bardua et al., 2019; Marshall et al., 2019; among others). 
To evaluate sesamoid evolution in these amphibian groups, and to fill the knowledge gap about them, we present a sesamoid distribution survey. Our main goals were:

1. to contribute to the knowledge of the comparative anatomy of bony or cartilaginous sesamoids in Lissamphibia,

2. to infer the evolutionary history of selected sesamoids in Lissamphibia.

Based on the available evidence of distribution patterns of bony and cartilaginous sesamoids in the remaining tetrapods, we consider that the lack of sesamoid records in urodeles and caecilians is probably due to sampling error. We expect to find bony or cartilaginous sesamoids in both groups: cranial sesamoids in Gymnophiona -due to its lack of limbs- and cranial and postcranial sesamoids in Caudata.

To achieve our goals, we studied about 850 specimens belonging to 280 taxa from dissected specimens, scanned specimens from different digital morphological databases, and literature data.

\section{Materials and Methods}

Sesamoids were examined in the skeleton of specimens from the herpetological collections of the Field Museum of Natural History, USA (FMNH), and Fundación Miguel Lillo, Argentina (FML). Material from three morphological databases was also reviewed: Morphosource (morphosource.org), Digimorph (http://digimorph.org/), and Phenome10k (phenome10k.org) (Supplementary Material S1). Adult and juvenile specimens representing all nine extant families (and one extinct family), 73 genera and 212 species (including 12 fossil species) of Caudata (571 specimens); nine (one extinct) of 11 families, 29 genera and 44 species (including one fossil species) of Gymnophiona (173 specimens); and 24 species of Temnospondyli and Lepospondyli 
(17 families) (Supplementary Material S1) were studied in detail. Dry skeletons and cleared and stained specimens of the collections were examined under a Meiji EMZ-5 binocular microscope. Clearing and staining allowed us to distinguish bony and cartilaginous structures. Unfortunately, since specimens were from the skeleton collection, it was not possible to determine age specifications, fixing conditions or loss of bones with soft tissue in the samples. However, our data on high-resolution X-ray computed tomography of specimens from digital databases allowed us to observe the internal structure of organisms without damaging the specimens, thus avoiding the problem of loss of bones with soft tissue.

Two individuals of Pleuredeles waltl were dissected to corroborate the identity of the ligaments or tendons related to the sesamoids. One specimen (FML30803) was completely cleared, while the other (FML30804) was partially cleared, and both were stained following the protocol of Wassersug (1976), with modifications. Furthermore, some specimens in the FMNH collection were partially transparent (e.g., Ambystoma mexicanum FMNH22888), allowing the identification of tendons and associated muscles. Photographs were taken with a Nikon Coolpix P6000 camera, and with a Leica, MZ7.5 stereomicroscope equipped with a Spot Insight Color Model\# 3.2.0 camera. The selected specimens were photographed with a DSLR camera, illuminated by light in the blue spectrum. The photos were taken through a yellow long-pass filter (which filters out any reflected light source, allowing only the fluorescent light to pass through). This visualization method of cleared and stained specimens was first described by Smith et al. (2018). To compile the sesamoids described for urodeles and caecilians, the literature on myology and osteology of these groups was reviewed.

Descriptions of 66 species of Caudata and 40 species of Gymnophiona were also considered (see species and literature cited in Supplementary Material S1). The presence or 
absence of bony or cartilaginous sesamoids in each of the 280 studied taxa was recorded. Based on both our survey and the literature, the presence, number, and type of bony or cartilaginous sesamoids in urodeles and caecilians were inferred. These relationships were expressed through a probability calculation (Table 1). Our survey included extant species, although descriptions of fossil species were also revised (Supplementary Material S1). Because heterotopic elements are often overlooked in morphological studies, and several of the reviewed studies are descriptions of the skull only, results from literature sources (Supplementary Material S1) should be interpreted with caution. The topology of a suite of anatomical characters (skeletal elements, tendons, ligaments, and muscles) as the main argument to elucidate sesamoid homologies was analyzed (Benjamin \& Ralph, 1998; Ponssa et al., 2010; Amador et al., 2018).

\section{Character evolution}

The obtained data were combined in a character matrix (Supplementary Material S2), where the sesamoids were included as characters and coded as present or absent. For the reconstruction of ancestral states, data from the sesamoid matrix were optimized onto a pruned version of the Caudata phylogeny of Bonnet \& Blair (2017), and Pyron \& Wiens (2011) for species that were not included in the most recent phylogeny. The tree was generated using TNT software (Goloboff et al., 2008) and the optimization was performed with Winclada software (Nixon, 1999), using the default setting (unambiguous mode). Sesamoids terminology follows Ponssa et al. (2010) and Abdala et al. (2019). We included each sesamoid in a different column of our data set (Supplementary Material S2), thus proposing their primary homology, i.e., we propose that all sesamoids belonging to the same column are the same by inheritance (De Pinna, 1991). The proposal of primary homology is based on reasonable assessment, in this case, topology 
(Agnarsson \& Coddington, 2008). However, if they fail the test of congruence and did not constitute synapomorphies on the selected cladogram, then they would not be secondary homologs (De Pinna, 1991). The cladogram allows us to test congruence and the hypothesis of secondary homology of the cranial sesamoid in salamanders.

\section{Results}

Three bony or cartilaginous sesamoids in Caudata were identified. One sesamoid is located on the mandibular symphysis of Necturus beyeri (Fig. 1A) and Amphiuma tridactylum. Another is a mandibular sesamoid, adjacent to the jaw articulation. The latter sesamoid is the most frequent and the one that has been most deeply studied. It is embedded in the ligament between the quadrate and prearticular bones (Fig. 2 and 3). The descending ramus of the squamosal is rectangular, flat, and fused to the quadrate. The quadrate is broad; its lateral margins attach to the levator mandibulae muscles anteriorly, and posteriorly to the depressor mandibulae muscle. The ventral margin of the quadrate meets with the terminal end of the mandible. The articular bone is visible as a prominence that articulates dorsally with the quadrate, located between the prearticular and dentary (in addition to sesamoids) in some species. The bony sesamoid is located within the ligament between both the quadrate and the articular or prearticular (Fig. 2C), slightly displaced posteriorly and medially. The sesamoid is present in 12 species of seven families: Peradactylodon persicus (Hynobiidae) (Fig. 1D), Cryptobranchus alleganiensis (Cryptobranchidae), Ambystoma jeffersonianum, Ambystoma mexicanum, and Ambystoma tigrinum (Ambystomatidae), Notophthalmus meridionalis, Notophthalmus viridescens, and Neurergus crocatus, Pleurodeles waltl (Salamandridae), Plethodon glutinosus (Plethodontidae), Necturus maculosus (Proteidae), and Siren intermedia (Sirenidae) (Figs. 2 and 3). The presence 
of this sesamoid is variable, and sometimes it is asymmetrically distributed in the same specimen, i.e., being present on one side of the skull (e.g., Ambystoma mexicanum, FMNH22888; Pleuredeles waltl, FML30804). Another sesamoid was observed between the skull and the lower jaw in Hydromantes platycephalus and Karsenia koreana (Plethodontidae). It is located at the posterior end of the maxilla (Fig. 1B and C). Isolated structures identified as "occasional elements" are observed, which are present laterally to the terminal and subterminal phalanx of the hands in, e.g., Ambystoma mexicanum (FMNH22888) (Fig. 4A) and Gyrinophilus porphyriticus (UF64645). No other cartilaginous or bony sesamoids are observed in the postcranium of the analyzed sample of urodeles. In the analyzed species of Gymnophiona, no bony or cartilaginous sesamoids are found, but occasional elements are observed surrounding the skull of some species, as in Ichthyophis bannanicus (MVZ 236728) (Fig. 4B).

The samples of Caudata and Gymnophiona are representative in terms of the number of species, with slightly more than $94 \%$ confidence. For a clearer indication that the absence or scarcity of cranial and postcranial bony or cartilaginous sesamoids in Caudata and Gymnophiona can indeed be considered an evidence of absence, a probability calculation based on the dataset is included. Considering the analyzed species, the probability of non-occurrences of bony or cartilaginous cranial sesamoids in Caudata is very high (98\%, see Table 1). On the other hand, the probability of non-occurrence of bony or cartilaginous postcranial sesamoids in Caudata and of bony or cartilaginous cranial and postcranial sesamoids in Gymnophiona is 100\% (Table 1).

\section{Sesamoid evolution}

The survey resulted in a very representative dataset, since all nine families of Caudata were studied. Optimization of the sesamoid in the mandibular symphysis shows that it is a convergent 
acquisition (Fig. 5). The mapping analyses of the mandibular sesamoid dataset onto the phylogeny reveal its convergent appearance in seven families (Fig. 5), thus rejecting the secondary homology proposal. The optimization was ambiguous at the base of the clades of the Notophthalmus species, and at (Ambystoma tigrinum $+A$. ordinarium). In the Hydromantes platycephalus + Karsenia koreana (Plethodontidae) clade, the presence of the sesamoid between the maxilla and the lower jaw wasoptimized as a putative synapomorphy (Fig. 5).

\section{Discussion}

Our survey of sesamoids in Caudata indicates that the only three bony or cartilaginous sesamoids present in the group are associated with the mandible: one with the symphysis, another with the quadrate-articular joint of the skull, and another between the maxilla and the lower jaw. As far as we know, this report provides the first record of sesamoids in the mandibular symphysis and at the posterior end of the maxilla of tetrapods. No sesamoids were observed in the postcranial joints. Furthermore, in Gymnophiona, no bony or cartilaginous sesamoids were observed.

The very conspicuous sesamoid in the mandibular symphysis suggests some kind of particular mechanical stress acting on the mandible of Necturus beyeri and Amphiuma tridactylum, although its presence in only these two taxa makes the ecological or biomechanical inferences excessively speculative. On the contrary, the sesamoid located between the maxilla and the lower jaw is a new synapomorphy that supports the node of Hydromantes platycephalus and Karsenia coreana.

The pool of species reviewed in this study showed that the mandibular sesamoid is present in seven of the nine families included in the order. However, that sesamoid is infrequent at the specific level, since it is present in only 16 of the 212 examined species (the order includes 
757 recognized species; Frost, 2020). The skulls of some species in which sesamoids were observed were previously described, but those descriptions included no reference to sesamoids; e.g., Siren intermedia (Reilly \& Altig, 1996), Ambystoma tigrinum (Naylor, 1978; Pedersen, 1993; Reilly \& Lauder, 1990), Notophthalmus viridiscens (Naylor, 1978; Reilly, 1986); Pleurodeles waltl (Corsin, 1966). Buckley et al. (2010) described the skull of Karsenia koreana based on the same specimen reviewed in this work (DRV5033). However, they did not mention the sesamoid between the maxilla and the lower jaw, although it is very conspicuous in their illustrations (see fig 2 A-D of Buckley et al. 2010).

The optimization of the mandibular sesamoid reveals its convergent appearance in the different families; thus, the secondary homology proposal is rejected. According to our optimization, the absence of this sesamoid is plesiomorphic to Caudata. Three and 15 species of the most basal families, Cryptobranchidae (including four species; Frost, 2020) and Hynobiidae (including 81 species; Frost, 2020), respectively, were reviewed and one species with a bony or cartilaginous mandibular sesamoid was recorded in each family. The descriptions of 12 Caudata fossil species were reviewed, and none of them mentioned the presence of sesamoids. The stemgroup of salamanders occurred during the Middle Jurassic, and was represented by species such as Karaurus sharovi (Karauridae), Kokartus honoraius (Karauridae), and Marmorerpeton kermaki (Incertae sedis) (Ivakhnenko, 1978; Evans et al., 1988; Gao \& Shubin, 2003; Carroll, 2007). These specimens and the first crown-group of Caudata, represented by Chunerpeton (Cryptobranchidae) of the Middle Jurassic and Beiyanerpeton and Qinglong triton (Salamandroidea) of the Late Jurassic (Gao \& Shubin, 2013; Gao et al., 2013; Jia \& Gao, 2016), are remarkably well-preserved fossils and do not present sesamoids. Even when more hynobiidae should be sampled, the available evidence of the basal clade Hynobiidae + Cryptobranchidae and 
the fossil record support the hypothesis of the absence of sesamoids as a plesiomorphic state in Caudata.

We propose the mandibular sesamoid of Caudata as a primary homology to that of anurans. However, in this group, the sesamoid has only been reported in Barbourula busuangensis (Clarke, 1987; Roček et al., 2016) and Chacophrys pierotti (Fabrezi et al., 2017) and, based on our findings, now in Alytes obstetricans (Alytidae, see https://www.morphosource.org/Detail/MediaDeandtail/Show/media_id/13730), Kassinula witei (Hyperoliidae, see https://www.morphosource.org/Detail/MediaDetail/Show/media_id/21067)

Silvertoneia

flotator (Dendrobatidae, see https://www.morphosource.org/Detail/MediaDetail/Show/media_id/63791); Barycholos pulquer (Craugastoridae, see https://www.morphosource.org/Detail/MediaDetail/Show/media_id/14710); Ansonia mcgregori (Bufonidae, see https://www.morphosource.org/ Detail/MediaDetail/Show/media_id/14201). It is likely to be present in a wider sample of anurans and might be considered present in the developmental program of the group. In Barbourula busuangensis, the sesamoid was described in the ligament, passing from the squamosal shaft to the posterior end of the angular bone of the mandible (Clarke, 1987; Roček et al., 2016). According to its topology and related ligament, in salamanders and anurans the sesamoid would meet the proposed primary homology criterion. However, a wider taxon sampling is needed to test the secondary homology of this sesamoid in Caudata and Anura.

Three groups of hypotheses about the origin of frogs, salamanders and caecilians persist in the literature: the "temnospondyl hypothesis", the "lepospondyl hypothesis", and the "polyphyly hypothesis", of which the former was the most widely supported for a long time (Ruta \& Coates, 2007). However, recent re-analyses strongly support the lepospondyl origin of 
lissamphibians (Marjanović \& Laurin, 2013, 2019). Whatever the affinities of the three modern orders with Paleozoic amphibians, the records of temnospondyls and lepospondyls do not include sesamoids (e.g., Walsh, 1987; Gardner, 2003, Carrol, 2007; Fortuny et al., 2016; see species in Supplementary Material S1). Further research is needed to find out whether fibrocartilaginous sesamoids are absent in these groups as well. Sesamoids are identified "in relation to" other anatomical elements, such as ligaments, tendons, and joints (Fontanarrosa et al., 2020). In disarticulated fossil remains, sesamoids are challenging to identify, which might explain their report in association with postcranial joints in only two fossils of the anuran Xenopus (Henrici \& Báez, 2001; Wang et al., 2007).

The proposed functions of sesamoids include protecting tendons against friction, compression, tension, or injuries (Sarin et al., 1999; Otero \& Hoyos, 2013; Regnault et al., 2016; Abdala et al., 2017; Zhang et al., 2017). The integration of the mandibular sesamoids with other elements of the mandibular joint (bones, muscles, tendons, and ligaments) would be crucial to generate the strength for feeding through complex and coordinated movements. Interestingly, it is not possible to propose a direct relationship between dietary selection or feeding habits and the presence of a mandibular sesamoid. Species with a mandibular sesamoid have a similar diet to that of species without sesamoids: they are predators with a wide range of prey types and sizes, from macroinvertebrates to small vertebrates, including annelids, mollusks, ants, spiders, centipedes, snails, sowbugs, beetles, mayflies, stoneflies, fish, amphibians, etc. (Hamilton, 1932; Bardwell et al., 2007). In a physiological position, the sesamoid fits between the squamosal and the prearticular, and is located among the jaw bones instead of covering the joint, the most common position of sesamoids. More comparative data is necessary to test the hypothesis of biomechanical restrictions linked to feeding and development of the mandibular sesamoids. 
We prefer not to include among sesamoids the occasional elements found in of Ambystoma mexicanum, Gyrinophilus porphyriticus, and Ichthyophis bannanicus, among others, due to their somewhat anecdotal record. Thus, we believe they should be considered occasional structures (see also Kunc et al., 2020) until their location embedded in a tendon is confirmed with histological studies.

The absence of bony or cartilaginous postcranial sesamoids in salamanders is striking and would be another particular characteristic of their limbs. Limbs of salamanders have a unique development among extant tetrapods, since they are characterized by the absence of the apical ectodermal ridge and the formation of the distal mesopodial and autopodial elements without a continuous condensation linking them to more proximal cartilages (Shubin \& Alberch, 1986; Franssen et al., 2005; Fröbisch \& Shubin, 2011; Kumar et al., 2015; Kearney et al., 2018). In the context of limb development of urodeles, several morphological patterns resulting from heterochrony -timing differences in development- have been described (e.g., Wake et al., 1983; Blanco \& Alberch, 1992; Shubin, 2002). These patterns consist of variations in the stages at which the fore and hind limbs develop (Smith, 1912; Hanken, 1982; Babcock \& Blais, 2001; Nye et al., 2003; Bininda-Emonds et al., 2007), or in the sequences in which several skeletal elements develop in the limbs (Shubin \& Alberch, 1986). In the absence of the AER, the small plethodontid Bolitoglossa occidentalis lacks phalangeal elements, which is interpreted as a paedomorphic character (Alberch \& Alberch, 1981). Sesamoids develop later than the other skeletal elements of anuran limbs (Ponssa et al., 2010; Vera \& Ponssa, 2014; Vera et al., 2015); thus, their absence in the salamander clade (both in large and small species), can be speculated to be a paedomorphic pattern, as a consequence of a truncated development. Whether this pattern is produced by the absence of the AER or any other changes in developmental mechanisms remains 
to be investigated. Interestingly, the limb joints of urodeles are also highly paedomorphic. The articular surfaces of the long limb bones are rather simple, remain cartilaginous, and lack secondary ossification centers (Haines, 1942; Meng et al., 2019) and the complexities present in the concave bony epiphyses of other tetrapods (see e.g., Hanken 1982, Fig. 4B) (Fig. 6). These simple structures might explain the lack of bony or cartilaginous sesamoids, since the tendons would not be subjected to the pressure and effort of sliding on a hard and sculpted surface.

There are no records of postcranial sesamoids in salamanders, caecilians, branchiosaurids, or other lepospondyls and temnospondyls (Walsh, 1987; Carrol, 2007; Fortuny et al., 2016; Gardner, 2001; Gruntmejer et al., 2016). An excellent fossil record of Paleozoic branchiosaurids presents a clear view of the limb ossification pattern in the Temnospondyli Apateon (Fröbisch et al., 2007), which lacks sesamoids. The process of limb ossification in Apateon is similar to that of urodeles in some aspects, such as the preaxial dominance in limb development or the limb ossification sequence, which has been discussed as a critical character to elucidate the relationship of these taxa (Fröbisch et al., 2007; Fröbisch, 2008). When plotted on the hypothesis of lissamphibian relationships to basal tetrapods, postcranial sesamoids require two steps to achieve a convergent evolution with postcranial sesamoids present in frogs and amniotes (Fig. 7). The absence of postcranial sesamoids results in the plesiomorphic state in tetrapods.

Caecilians are elongated, snake-like amphibians, completely lacking limbs and girdles. They have a terrestrial, surface-cryptic, or burrowing lifestyle, except for Typhlonectidae, whose members are secondary aquatic or semi-aquatic (Taylor, 1968; Estes, 1981; Wilkinson \& Nussbaum, 1999). The lack of postcranial sesamoids could be a logical consequence of the lack of postcranial joints of the crown group Gymnophiona. However, in the two putative stem- 
groups of caecilians, Eocaecilia micropodia from the Lower Jurassic, which has reduced limbs (Jenkins \& Walsh, 1993), and Rubricacaecilia monbaroni from the Lower Cretaceous, to which a left femur showing a trochanteric crest has been tentatively attributed (Evans \& SigogneauRussel, 2001), no sesamoids have been reported. According to the dynamic model proposed in Abdala et al. (2019), sesamoids can attach to and detach from the long bone epiphyses and diaphyses during both ontogeny and phylogeny (see also Parsons, 1904; Manners-Smith, 1908; Barnett \& Lewis, 1958; Cheong et al., 2017, among many others). Thus, the observed trochanteric crest could be interpreted as an attached sesamoid. New fossil evidence could fill the information gap about sesamoid evolution in this group.

Since caecilians are limbless and mainly fossorial animals, the diversification of their cranium might have been conditioned by the functional demands of head burrowing (Sherratt $e t$ al., 2014). This fossorial mode of life might have been the most substantial influence on the parietal and quadrate-squamosal modules (Bardua et al., 2019). This strong integration of the skull bones could explain the lack of sesamoids in the quadrate-squamosal module. Moreover, the rearrangement of jaw-closing muscles across Gymnophiona influences the jaw joint (Bardua et al., 2019). The involved tendons would not be subjected to the necessary tension threshold for the development and evolution of sesamoids in this group.

The tissue composition of sesamoids can be diverse and can include cartilage, bone, or fibrocartilage. In the latter case, histological samples would be necessary to corroborate its presence or absence in salamanders and caecilians.

Conclusions 
Our data show the presence of three cranial bony sesamoids in Caudata, which is remarkable considering that cranial sesamoids are rare among tetrapods. Our data also indicate that Caudata lacks bony or cartilaginous postcranial sesamoids, whereas Gymnophiona lacks bony or cartilaginous cranial and postcranial sesamoids. Our ancestral state reconstruction indicates that the plesiomorphic state to the Caudata is the absence of bony or cartilaginous cranial sesamoids.

\section{ACKNOWLEDGMENTS}

We thank Santiago Nenda (MACN) for providing study material, G. Fontanarrosa for her comments on the manuscript, and S. Nannis for her help with English. M.L.P is very grateful to Alan Resetar and Joshua Mata for their hospitality in the herpetology collection of the FMNH.

M.L.P. We thank Jennifer Y. Lamb for the fluorescent light photos. Morphosource.org and DigiMorph.org, and Ambibia Tree authorized the use of images. We are also thankful to J. M. Hoyos (Pontificia Universidad Javeriana, Colombia), and two anonymous reviewers for their help in improving our work.

\section{Literature Cited}

Abdala V, Vera MC, Ponssa ML. 2017. On the presence of the patella in frogs. The Anatomical Record 300:1747-1755.

Abdala V, Vera MC, Amador LI, Fontanarrosa G, Fratani J, Ponssa ML. 2019. Sesamoids in tetrapods: the origin of new skeletal morphologies. Biological Reviews 94:2011-2032. 
Adriaens D, Verraes W. 1998. Ontogeny of the osteocranium in the African catfish, Clarias gariepinus Burchell (1822) (Siluriformes: Clariidae): ossification sequence as a response to functional demands. Journal of Morphology 235:183-237.

Alberch P, Alberch J. 1981. Heterochronic mechanisms of morphological diversification and evolutionary change in the neotropical salamander, Bolitoglossa occidentalis (Amphibia: Plethodontidae). Journal of Morphology 167:249-264.

Alexander R. 1967. The functions and mechanisms of the protrusible upper jaws of some acanthopterygian fish. Journal of Zoology 151:43-64.

Amador L, Giannini NP, Simmons N, Abdala V. 2018. Morphology and evolution of sesamoid elements in bats (Mammalia: Chiroptera). American Museum Novitates 3905: $1-40$.

Avilan P, Hoyos JM. 2006. Osteología de Eleutherodactylus bogotensis (Amphibia, Anura, Leptodactylidae) del parque nacional natural Chingaza (Cundinamarca, Colombia). Caldasia 28:89-109.

Babcock SK, Blais JL. 2001. Caudal vertebral development and morphology in three salamanders with complex lifecycles (Ambystoma jeffersonianum, Hemidactylium scutatum, and Desmognathus ocoee). Journal of Morphology 247:142-159.

Bardua C, Wilkinson M, Gower DJ, Sherrat E, Goswani A. 2019. Morphological evolution and modularity of the caecilian skull. BMC Evolutionary Biology 19:30 doi.org/10.1186/s12862-018-1342-7.

Bardwell JH, Ritzi CM, Parkhurst JA. 2007. Dietary selection among different size classes of larval Ambystoma jeffersonianum (Jefferson Salamanders). Northeastern Naturalist 14(2): 293-299. 
Barnett CH, Lewis OJ. 1958. The evolution of some traction epiphyses in birds and mammals. Journal of Anatomy 92:593-601.

Bemis WE, Schenk K, Wake MK. 1983. Morphology and function of the feeding apparatus in Dermophis mexicanus (Amphibia: Gymnophiona). Zoological Journal of the Linnean Society 77:75-96.

Benjamin M, Ralphs JR. 1998. Fibrocartilage in tendons and ligaments-an adaptation to compressive load. Journal of Anatomy 193:481-494.

Bininda-Emonds ORP, Jeffery JE, Sánchez-Villagra MR, Hanken J, Colbert M, Pieau C, Selwood L, Ten CC, Raynaud A, Osabutey CK, Richardson MK. 2007. Forelimb-hind limb developmental timing changes across tetrapod phylogeny. BMC Evolutionary Biology 7:182.

Blanco M, Alberch P. 1992. Caenogenesis, developmental variability, and evolution in the carpus and tarsus of the marbled newt Triturus marmoratus. Evolution, 46(3): 677-687. http://doi.org/10.1111/j.1558-5646.1992.tb02075.x

Bonnet RM, Blair AL. 2017. Evidence for complex life cycle constraints on salamander body form diversification. Proceedings of the National Academy of Science doi.org/10.1073/pnas.1703877114.

Bramble DM. 1974. Occurrence and significance of the ostransiliens in gopher tortoises. Copeia 1:102-109.

Cala CJD, Tarazona OA, Ramírez-Pinilla MP. 2019. The morphology and post-hatching development of the skull of Bolitoglossa nicefori (Caudata: Plethodontidae): developmental implications of recapitulation and repatterning. Zoology 112:227-239. 
Carlsöö S. 1982. The effect of vibration on the skeleton, joints, and muscles: a review of the literature. Applied Ergonomics 13(4):251-258.

Carroll RL. 2007. The palaeozoic ancestry of salamanders, frogs, and caecilians. Zoological Journal of the Linnean Society 150:1-140.

Cheong I, Kang H, Ko H, Sung J, Song Y, Hwang, J. 2017. Genetic influence on accessory navicular bone in the foot: a Korean twin and family study. Twin Research and Human Genetics 20: $236-241$.

Clarke BT. 1987. A description of the skeletal morphology of Barbourula (Anura: Discoglossidae), with comments on its relationships. Journal of Natural History 21:879-891.

Corsin J. 1966. The development of the osteocranium of Pleurodeles waltl Michahelles. Journal of Morphology 119:209-216.

Chadwick KP, Regnault S, Allen V, Hutchinson J R. 2014. Three-dimensional anatomy of the ostrich (Struthio camelus) knee joint. PeerJ, 2, e706.

Datovo A, Bockmann FA. 2010. Dorsolateral head muscles of the catfish families Nematogenyidae and Trichomycteridae (Siluriformes: Loricarioidei): Comparative anatomy and phylogenetic analysis. Neotropical Ichthyology 8:193-246.

Denyer AL, Regnault S, Hutchinson JR. 2020. Evolution of the patella and patelloid in marsupial mammals. PeerJ8:e9760https://doi.org/10.7717/peerj.9760

Diogo R, Oliveira C, Chardon M. 2001. On the homologies of the skeletal components of catfish (Teleostei: Siluriformes) suspensorium. Belgian Journal of Zoology 131:93-109.

Diogo R, Walsh S, Smith C, Ziermann JM, Abdala V. 2015. Towards the resolution of a longstanding evolutionary question: muscle identity and attachments are mainly related to 
topological position and not to primordium or homeotic identity of digits. Journal of Anatomy 226:523-529.

Estes R. 1981. Gymnophiona, Caudata. In Handbuch der Palaeoherpetologie. Vol. 2.Kuhn O (coord). Gustav Fischer Verlag. Stuttgart. 115 pp.

Evans SE, Milner AR, Musset F. 1988. The earliest known salamanders (Amphibia, Caudata): a record from the Middle Jurassic of England. Geobios 21:539-552.

Evans SE, Sigogneau-Russel D. 2001. A stem-group caecilian (Lissamphibia: Gymnophiona) from Lower Cretaceous of North Africa. Paleontology 44:259-273.

Fabrezi M. 2006. Morphological evolution of Ceratophryinae (Anura, Neobatrachia). Journal of Zoological Systematics and Evolutionary Research 44:153-166.

Fontanarrosa G, Fratani J, Vera MC. 2020. Delimiting the boundaries of sesamoid identities under the network theory framework. PeerJ, DOI 10.7717/peerj.9691.

Fortuny J, Marce-Nogue J, Steyer JS, De Esteban-Trivigno S, Mujal E, Gil L. 2016. Comparative 3D analyses and palaeoecology of giant early amphibians (Temnospondyli: Stereospondyli). Scientific Reports 6:1-10.

Franssen RA, Marks S, Wake D, Shubin N. 2005. Limb chondrogenesis of the seepage salamander, Desmognathus aeneus (Amphibia: Plethodontidae). Journal of Morphology 265:87-101.

Fröbisch NB, Carroll RL, Schoch RR. 2007. Limb ossification in the Paleozoic branchiosaurid Apateon (Temnospondyli) and the early evolution of preaxial dominance in tetrapod limb development. Evolution \& Development 9:69-75. 
Fröbisch NB, Shubin NH. 2011. Salamander limb development: integrating genes, morphology, and fossils. Developmental Dynamics 240:1087-1099.

Frost DR. 2020. Amphibian Species of the World: an Online Reference. Version 6.0 (Date of $\begin{array}{llll}\text { access). } & \text { Electronic } & \text { Database accessible at }\end{array}$ http://research.amnh.org/herpetology/amphibia/index.html. American Museum of Natural History, New York, USA. doi.org/10.5531/db.vz.0001

Gao KQ, Shubin NH. 2003. Earliest known crown-group salamanders. Nature 422:424-428.

Gao K, Chen J, Jia J. 2013. Taxonomic diversity, stratigraphic range, and exceptional preservation of Juro-Cretaceous salamanders from northern China. Canadian Journal of Earth Sciences 50:255-267.

Gardner JD. 2003. The fossil salamander Proamphiuma cretacea Estes (Caudata; Amphiumidae) and relationships within the Amphiumidae. Journal of Vertebrate Paleontology 23:769-782.

Gauthier JA, Kearney M, Maisano JA, Rieppel O, Behlke AD. 2012. Assembling the squamate tree of life: Perspectives from the phenotype and the fossil record. Bulletin of the Peabody Museum of Natural History 53:3-308

Goloboff PA, Farris JS, Nixon KC. 2008. TNT, a free program for phylogenetic analysis. Cladistics 24:774-786.

Gruntmejer K, Konietzko-Meier D, Bodzioch A. 2016. Cranial bone histology of Metoposaurus krasiejowensis(Amphibia, Temnospondyli) from the Late Triassic of Poland. PeerJ DOI 10.7717/peerj.2685 
Guayasamin JM. 2004. A new species of Eleutherodactylus (Anura: Leptodactylidae) from the northwestern lowlands of Ecuador. Herpetologica 60:190-191.

Gussekloo WS, Bout RG. 2005. Cranial kinesis in paleognathous birds. Journal of Experimental Biology 208:3409-3419.

Haines RW. 1942. The evolution of epiphyses and of endochondral bones. Biological Reviews 17:267-292.

Hamilton WJ Jr. 1932. The food and feeding of some eastern salamanders. Copeia 1932:83-86.

Hanken J. 1982. Appendicular skeletal morphology in minute salamanders, genus Thorius (Amphibia: Plethodontidae): growth regulation, adult size determination, and natural variation. Journal of Morphology 174:55-77.

Henrici AC, Baéz AM. 2001. First occurrence of Xenopus (Anura: Pipidae) on the Arabian Peninsula: a new species from the upper Oligocene of Yemen. Journal of Paleontology 75:870-882.

Hofling E, Gasc JP. 1984. Biomechanics of the skull and the beak in Ramphastos (Ramphastidae, Aves) I. Description of anatomical elements. Gegenbaurs Morphologisches Jahrbuch 130:125-147.

Holliday CM, Witmer LW. 2007. Archosaur adductor chamber evolution: Integration of musculoskeletal and topographical criteria in jaw muscle homology. Journal of Morphology 268:457-484.

Hoyos JM. 2003. Additions to our knowledge of anuran sesamoids. Herpetological Review 34:112-116.

Iordansky NN. 1964. The jaw muscles of the crocodiles and some relating structures of the crocodilian skull. Anatomischer Anzeiger 115:256-280. 
Iordansky NN. 1989. Evolution of cranial kinesis in lower tetrapods. Netherlands Journal of Zoology 40:32-54.

Ivakhnenko MF. 1978. Urodelans from the Triassic and Jurassic of Soviet Central Asia. Paleont. Zhurnal, Moscow 1978 (3):84-89 (in Russian). Paleontological Journal 12(3):362368 (in English).

Jenkins DT, Walsh DM. 1993. An Early Jurassic caecilian with limbs. Nature 365:246-249.

Jerez A, Mangione S, Abdala V. 2010. Occurrence and distribution of sesamoid bones in squamates: a comparative approach. Acta Zoologica Stockholm 91:295-305.

Jia J, Gao K. 2016. A new basal salamandroid (Amphibia, Urodela) from the Late Jurassic of Qinglong Province, China. PLoS One 11(5):1-35. DOI: 10.1371/journal.pone.0153834.

Jia J, Jiang JP, Zhang MH, Gao KQ. 2018. Osteology of Batrachuperus yenyuanensis (Urodela, Hynobiidae), a high-altitude mountain stream salamander from western China. PLoS One 14(1): e0211069.

Kearney RR, Hanken J, Blackburn DC. 2018. Early limb patterning in the direct-developing salamander Plethodon cinereus revealed by sox 9 and col2a1. Evolution and Development 20:100-107.

\section{Khoshnamvand H, Malekian M, Keivany Y, Zamani-Faradonbe MZ, Amiri M. 2019.}

Descriptive osteology of an imperiled amphibian, the Luristan newt (Neurergus kaiseri, Amphibia. Salamandridae). Acta Herpetologica 14:51-56. 
Kumar A, Gates PB, Czarkwiani A, Brockes JP. 2015. An orphan gene is necessary for preaxial digit formation during salamander limb development. Nature Communications 6:8684-8688. http://doi.org/10.1038/ncomms9684

Kunc V, Kunc V, Černý V, Polovinčák M, Kachlík D. 2020. Accessory bones of the elbow: Prevalence, localization and modified classification. Journal of Anatomy 237:618-622. https://doi.org/10.1111/joa.13233

Laurent RF. 1961. Notes on Some South African Amphibians, Edition (Volume 1), pp.197209. Publications de l'Universite de l'Etata Elisabethville, Lubumbashi.

Laurin M. 1998. The importance of global parsimony and historical bias in understanding tetrapod evolution. Part I. Systematics, middle ear evolution, and jaw suspension. Annales des Sciences Naturelles. Zoologie (13 Ser.) 19:1-42.

Laurin M, Reisz RR. 1997. A new perspective on tetrapod phylogeny. In Sumida S, Martin K. (eds). Amniote Origins. Completing the Transition to Land. Academic Press, San Diego, 959.

Macaluso L, Villa A, Pitruzzella G, Rook L, Pogoda P. Kupfer M, Delfino, M. 2020. Oteology of the Italian endemic spectacled salamanders, Salamandrina spp. (Amphibia, Urodela, Salamandridae): selected skeletal elements for palaeontological investigations. Journal of Morphology DOI: 10.1002/jmor.21254

Manners-Smith T. 1908. A study of the cuboid and os peroneum in the primate foot. Journal of Anatomy and Physiology 42:397-414.

Marjanović D, Laurin M. 2013.The origin(s) of extant amphibians: a review with emphasis on the "lepospondyl hypothesis". Geodiversitas 35:207-272. 
Marjanović D, Laurin M. 2019. Phylogeny of Paleozoic limbed vertebrates reassessed thorough revision and expansion of the largest published relevant data matrix. PeerJDOI 10.7717/peerj.5565.

Marshall AF, Bardua C, Gower DJ, Wilkinson M, Sherrat E, Goswami A. 2019. Highdensity three-dimensional morphometric analyses support conserved static (intraspecific) modularity in caecilian (Amphibian: Gymnophiona) crania. Biological Journal of the Linnean Society 126:721-742.

Meng X, Goldin P, Herdina AN, Estefa J, Medvedeva EV, Li L, Newton PT, Kotova S, Shavkuta B, Saxena A, Shumatel LT, Metscher B, Großschmidt K, Nishimori S, Akovantseva A, Linares Arregui I, Tafforeau P, Fried K, Carlström M, Simon A, Gasser C, Kronenberg HM, Bastepel M, Cooper K, Timashev P, Sanchez S, Adameyko I, Eriksson A, Chagin AS. 2019. Secondary ossification centers evolved to make endochondral bone growth possible under the weight bearing demands of a terrestrial environment. Bio Rxiv preprint doi: https://doi.org/10.1101/571612.

Milner AR. 1993.Amphibian-grade Tetrapoda, in Benton MJ (ed.). The Fossil Record 2. Chapman \& Hall, London, 665-679.

Montero R, Daza JD, Bauer AM, Abdala V. 2017. How common are cranial sesamoids among squamates? Journal of Morphology 278:1400-1411.

Müller H. 2006. Ontogeny of the skull, lower jaw, and hyobranchial skeleton of Hypogeophis rostratus (Amphibia: Gymnophiona: Caeciliidae) Revisited. Journal of Morphology 267:967987.

Naylor BG. 1978. The frontosquamosal arch in newt as a defense against predators. Canadian Journal of Zoology 56:2211-2216. 
Nussbaum RA. 1982. Heterotopic bones in the hindlimbs of frogs of the families Pipidae, Ranidae, and Sooglossidae. Herpetologica 38:312-332.

Nye HL, Cameron JA, Chernoff EA, Stocum DL. 2003. Extending the table of stages of normal development of the axolotl: limb development. Developmental Dynamics 226:555560.

Olson WM. 2000. Phylogeny, ontogeny, and function: Extraskeletal bones in the tendons and joints of Hymenochirus boettgeri (Amphibia: Anura: Pipidae). Zoology 103:1524.

Otero T, Hoyos JM. 2013. Sesamoid elements in lizards. Journal of Herpetology 23:105-114.

Parsons FG. 1904. Observations on traction epiphyses. Journal of Anatomy 38:248-258.

Pearson K, Davin AG. 1921a. On the sesamoids of the knee-joint. Part I. Man. Biometrika 13: $133-175$.

Pearson K, Davin AG. 1921b. On the sesamoids of the knee-joint. Part II. Evolution of the sesamoids. Biometrika 13:350-400.

Pedersen SC. 1993. Skull growth in cannibalistic tiger salamanders, Ambystoma tigrinum. The Southwestern Naturalist 38(4):316-324.

Ponssa ML, Goldberg J, Abdala V. 2010. Sesamoids in anurans: new data, old issues. The Anatomical Record 293:1646-1668.

Pyron RA, Wiens JJ. 2011. A large-scale phylogeny of Amphibia including over 2800 species, and a revised classification of extant frogs, salamanders, and caecilians. Molecular Phylogenetic and Evolution 61:543-583. 
Regnault S, Pitsillides AA, Hutchinson JR. 2014. Structure, ontogeny, and evolution of the patellar tendon in emus (Dromaius novaehollandiae) and other palaeognathae birds. PeerJ 2, DOI: $10.7717 /$ peerj. 711 .

Regnault S, Hutchinson JR, Jones ME. 2016. Sesamoid bones in tuatara (Sphenodon punctatus) investigated with X-ray microtomography and implications for sesamoid evolution in Lepidosauria. Journal of Morphology 278:62-72.

Reilly SM. 1986. Ontogeny of cranial ossification in the eastern newt, Notophthalmusviridescens(Caudata: Salamandridae), and its relationship to metamorphosis and neoteny. Journal of Morphology 188:318-326.

Reilly SM, Lauder GV. 1990. Metamorphosis of cranial design in tiger salamanders (Ambystoma tigrinum): a morphometric analysis of ontogenetic change. Journal of Morphology 204:121-137.

Reilly SM, Altig R. 1996. Cranial ontogeny in Siren intermedia (Caudata: Sirenidae): paedomorphic, metamorphic, and novel patterns of heterochrony. Copeia 1996(1):29-41.

Restrepo AE. 1995. Comparación de la osteologìa de la salamandra Bolitoglossa adspersa (Urodela: Plethodontidae) con otros urodelos. Universitas Scientiarum 2:43-50.

Reyes-Amaya N, Jerez A, Flores D. 2017.Morphology and postnatal development of lower hindlimbs in Desmodus rotundus (Chiroptera: Phyllostomidae): A Comparative Study. The Anatomical Record 300:2150-2165.

Roček Z, Balleva N, Vazeille A, Bravin A, van Dijk E, Nemoz C, Přkryl T, Smirina EM, Boiste R, Claessens L. 2016. Contribution to the head anatomy of the basal frog Barbourula busuangensis and the evolution of the Anura. Russian Journal of Herpetology 23(3):163-194. 
Romankowowa A. 1961. The sesamoid bones of the autopodia of bats; Trzeszczkiodcinkawolnego (autopodium) konczynnietoperzy. Acta Theriologica 5:125-140.

Ruta M, Coates MI, Quicke DLJ. 2003. Early tetrapod relationships revisited. Biological Reviews 78: 251-345.

Ruta M, Coates MI. 2007. Dates, nodes, and character conflict: addressing the lissamphibian origin problem. Journal of Systematic Palaeontology 5:69-122 doi.10.1017/S1477201906002008.

Samuels ME, Regnault S, Hutchinson JR. 2017. Evolution of the patellar sesamoid bone in mammals. PeerJ 5:e3103 doi.10.7717/peerj.3103.

Sarin VK, Erickson GM, Giori NJ, Bergman AG, Carter DR. 1999. Coincident development of sesamoid bones and clues to their evolution. The Anatomical Record 257:174-180.

Sherratt E, Gower DJ, Klingenberg CP, Wilkinson M. 2014. Evolution of cranial shape in caecilians (Amphibia: Gymnophiona). Evolutionary Biology 41:528545.

Schumacher GH. 1973. The head muscles and hyolaryngeal skeleton of turtles and crocodilians. In C. Gans, A. D. Bellairs, \& T. S. Persons (Eds.), Biology of the Reptilia 4. Morphology D (pp. 101-200). New York: Academic Press.

Shubin NH, Wake DB, Crawford AJ. 1995. Morphological variation in the limbs of Taricha granulosa (Caudata: Salamandridae): evolutionary and phylogenetic implications. Evolution 49(5):874-884.

Shubin NH. 2002. Origin of evolutionary novelty: Examples from limbs. Journal of Morphology 252:15-28. doi:10.1002/jmor.10017 
Shubin NH, Alberch P. 1986. A morphogenetic approach to the origin and basic organization of the tetrapod limb. Evolutionary Biology 20:319-387.

Smith BG. 1912. The embryology of Cryptobranchus alleganiensis, including comparisons with other vertebrates. Journal of Morphology 23:579.

Smith WL, Chesney AB, Ornay GS, Davis MP, Martin RP, Gibson SZ, Girard MG. 2018. Improving vertebrate skeleton images: fluorescence and the non-permanent mounting of cleared and stained specimens. Copeia 106(3):427-435.

Summers AP, Koob-Emunds MM, Kajiura SM, Koob TJ. 2003. A novel fibrocartilaginous tendon from an elasmobranch fish (Rhinoptera bonasus). Cell and Tissue Research 312:221227.

Taylor EH. 1968. The caecilians of the world: a taxonomic review. Lawrence: University of Kansas Press. 848 p.

Trueb L., Cloutier R.1991.A phylogenetic investigation of the inter- and intrarelationships of the Lissamphibia (Amphibia: Temnospondyli), in Schultze HP, Trueb L. (eds), Origins of the Higher Groups of Tetrapods. Controversy and Consensus. Cornell University Press, Ithaca, $223-313$.

Tsai HP, Holliday CM. 2011. Ontogeny of the Alligator cartilage transiliens and its significance for sauropsid jaw muscle evolution. PLoSOne 6, e24935.

Vallin G, Laurin M. 2004. Cranial morphology and affinities of Microbrachis, and a reappraisal of the phylogeny and lifestyle of the first amphibians. Journal of Vertebrate Paleontology 24:56-72. 
Vera MC, Ponssa ML. 2014. Skeletogenesis in anurans: Cranial and postcranial development in metamorphic and postmetamorphic stages of Leptodactylus bufonius (Anura: Leptodactylidae). Acta Zoologica (Stockholm) 95(1):44-62 doi.org/10.1111/azo.12007

Vera MC, Ponssa ML, Abdala V. 2015. Further data on sesamoid identity from two anuran species. The Anatomical Record 298:1376-1394.

Vickaryous MK, Olson WM. 2007. Sesamoids and ossicles in the appendicular skeleton. In: Hall BK, editor. Fins into Limbs. pp. 323-341. The University of Chicago Press, Chicago.

Villa A, Andreone F, Boistel R. Delfino M. 2014. Skull and lower osteology of the Lanza's salamander, Salamandra lanzai (Amphibia, Caudata). Scripta Herpetologica. Studies on Amphibians and Reptiles in honor of Benedetto Lanza, pp.171-200.

Wake DB. 1963. Comparative osteology of the plethodontid salamander genus Aneides. Journal of Morphology 113:77-118.

Wake T, Wake D, Wake M. 1983. The ossification sequence of Aneides lugubris, with comments on heterochrony. Journal of Herpetology 17(1):10-22. doi:10.2307/1563775

Walsh DM. 1987. Systematics of the Caecilians (Amphibia: Gymnophiona). A thesis submitted to the Faculty of Graduate Studies and Research in partial fulfillment of the requirements for the degree of Doctor of Philosophy. 335 p.

Wang Y, Jones MEH, Evans SE. 2007. A juvenile anuran from the Lower Cretaceous Jiufotang Formation, Liaoning, China. Cretaceous Research 28:235e244.

Wassersug RJ. 1976. A procedure for differential staining of cartilage and bone in whole formalin-fixed vertebrates. Stain Technology 51:131-134. 
Wilkinson M, Nussbaum RA. 1999. Evolutionary relationships of the lungless caecilian Atretochoana eiselti (Amphibia: Gymnophiona: Typhlonectidae). Zoological Journal of the Linnean Society 126:191-223.

Wu Y, Wang Y, Hanken J. 2012. Comparative osteology of the genus Pachytriton (Caudata: Salamandridae) from Southeastern China. Asian Herpetological Research 3(2):83-102.

Zhang R, Han D, Luo G, Ling L, Li G, Ji Q, Li J. 2017. Macroscopic and microscopic analyses in flexor tendons of the tarso metatarso-phalangeal joint of ostrich (Struthio camelus) foot with energy storage and shock absorption. Journal of Morphology 279:302-311. 
706

\section{Figure Captions}

Fig. 1. Sesamoid in the mandibular symphysis of Necturus beyeri (UF177187), view of stl surface model of a cranial CT scan from MorphoSource, dataset https://doi.org/10.17602/M2/M39589 (A). Skulls of: Hydromantes platycephalus (uncatalogued), image credit: Digimorph.org (B), and Karsenia koreana (DRV5033) with a sesamoid between the posterior end of the maxilla and the lower jaw joint, image credit: Digimorph.org (C); Peradactylodon persicus (MVZ241494) with a sesamoid in the quadrate-prearticular joint, image credit: Digimorph.org. (D). The largest arrows show the sesamoids. dent=dentary, max=maxilla, preart=preartricular, sq=squamosal.

Fig. 2. Mandibular sesamoid in the quadrate-prearticular joint of the skull of Siren intermedia (FMNH84082) (A), Neurergus crocatus (FMNH19629)(B), Ambystoma mexicanum (FMNH22888) under white (C) and fluorescent lighting (photo credit: Jennifer Y. Lamb) (D), Ambystoma jeffersonianum (FMNH196112) (E), Necturus maculosus (FMNH21523) (F). Scale bar $=1 \mathrm{~mm}$. White arrow $=$ indicates the ligament surrounding the sesamoid in detail of the Ambystoma mexicanum mandibular joint.

Fig. 3. Mandibular sesamoid in the quadrate-prearticular joint of the skull of Notophthalmus viridiscens (FMNH93537) (A), Notophthalmus meridionalis (FMNH93536) under white (B) and fluorescent light (photo credit: Jennifer Y. Lamb) $(C, D)$. Scale bar $=1 \mathrm{~mm}$.

Fig. 4. Accessory structure lateral to the terminal and subterminal phalanx of hands in Ambystoma mexicanum (FMNH22888) (A), and surrounding the skull of Ichthyophis bannanicus (MVZ236728) image credit: Digimorph.org (B). 
Fig. 5. Salamander phylogeny used in the optimization analysis of mandibular sesamoid character follows relationships proposed by Bonnet \& Blair (2017) and Pyron \& Wiens (2011) for species not included in the most recent phylogeny. Mapping of sesamoid of the mandibular symphysis is indicated in green; mapping of mandibular sesamoid, located between the quadrate and prearticular bone is indicated in red; mapping of sesamoid between the skull and the lower jaw, located at the posterior end of the maxilla is indicated in blue.

Fig. 6. Examples of joints in salamanders and frogs showing the difference in the complexity of the joint surfaces. (A) Manus of the facultative paedomorphic species Pleurodeles waltl (FML30803) (B) Manus of the paedomorphic species Siren intermedia (FMNH84082) (C) Manus of the anuran species Leptodactylus latinasus (FML S/N), showing the glide sesamoids in the inter-phalangeal joints. (D) Hindlimb of Pleurodeles waltl (FML30803), the simple articular surfaces of the knee and ankle joints are evident. (E) Ankle and (F) Knee joints of Leptodactylus bufonius $(\mathrm{FML} \mathrm{S} / \mathrm{N})$ where the related sesamoids are visible. Scale bar $=1 \mathrm{~mm}$.

Fig. 7. The three discussed hypotheses of interrelationships of the three modern amphibian groups and their relationships to possible Paleozoic records. (A) Polyphyly hypothesis simplified from Ruta \& Coates (2007); (B) temnospondyl hypothesis (Trueb \& Clouthier, 1991; Milner, 1993; Ruta et al., 2003); (C) lepospondyl hypothesis (Laurin \& Reisz, 1997; Laurin, 1998; Vallin \& Laurin, 2004). Red bars indicate the presence of postcranial sesamoids (PS) as has been known until present. 


\section{Figure 1}

Cranial sesamoids in salamanders

Sesamoid in the mandibular symphysis of Necturus beyeri (UF177187), view of stl surface model of a cranial CT scan from MorphoSource, dataset https://doi.org/10.17602/M2/M39589 (A). Skulls of: Hydromantes platycephalus (uncatalogued), image credit: Digimorph.org (B), and Karsenia koreana (DRV5033) with a sesamoid between the posterior end of the maxilla and the lower jaw joint, image credit: Digimorph.org (C); Peradactylodon persicus (MVZ241494) with a sesamoid in the quadrate-prearticular joint, image credit: Digimorph.org.

(D). The largest arrows show the sesamoids. dent=dentary, max=maxilla, preart=preartricular, sq=squamosal. 


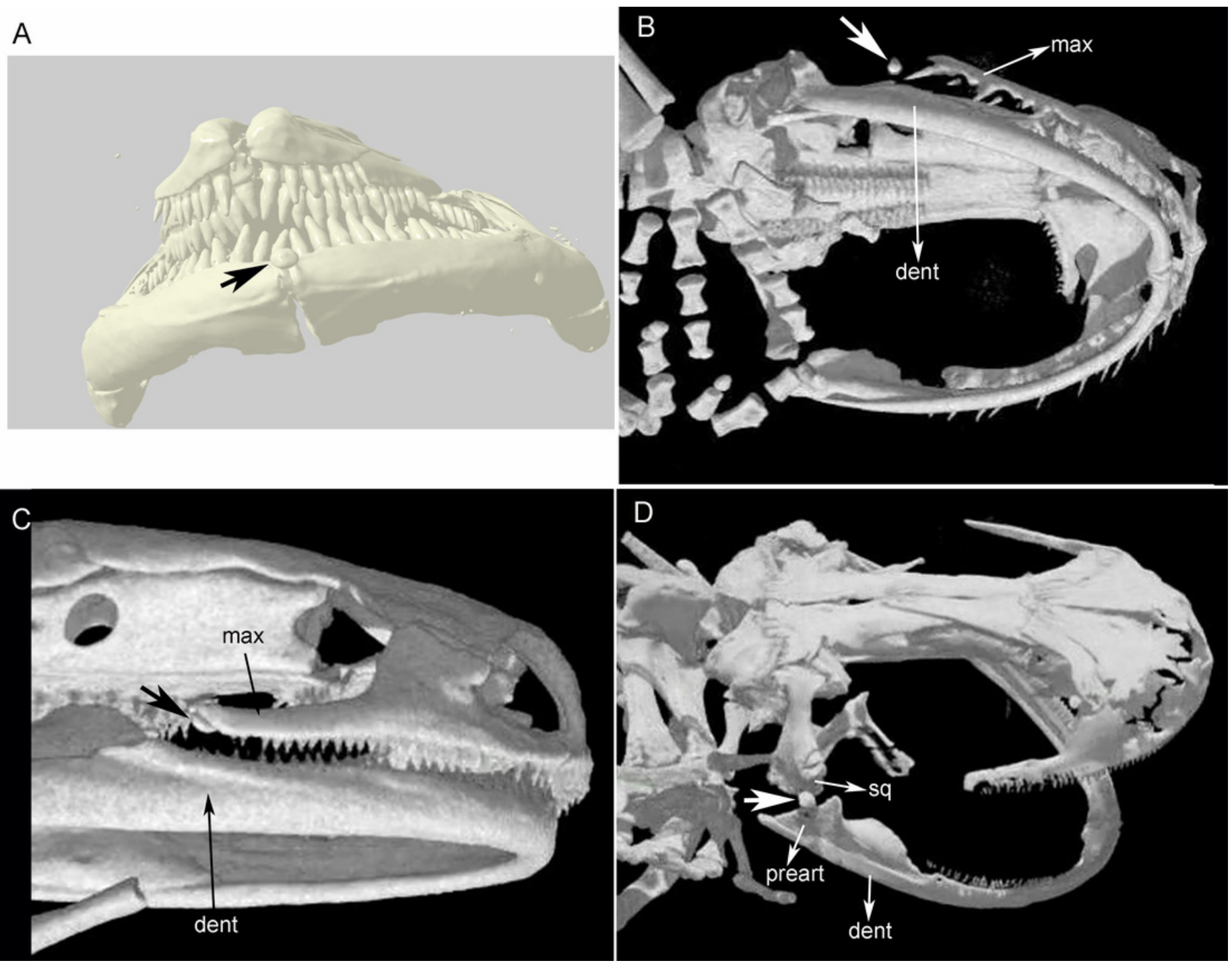




\section{Figure 2}

Cranial sesamoids in salamanders

Mandibular sesamoid in the quadrate-prearticular joint of the skull of Siren intermedia (FMNH84082) (A), Neurergus crocatus (FMNH19629)(B), Ambystoma mexicanum

(FMNH22888) under white (C) and fluorescent lighting (photo credit: Jennifer Y. Lamb) (D), Ambystoma jeffersonianum (FMNH196112) (E), Necturus maculosus (FMNH21523) (F). Scale bar $=1 \mathrm{~mm}$. White arrow $=$ indicates the ligament surrounding the sesamoid in detail of the Ambystoma mexicanum mandibular joint. 

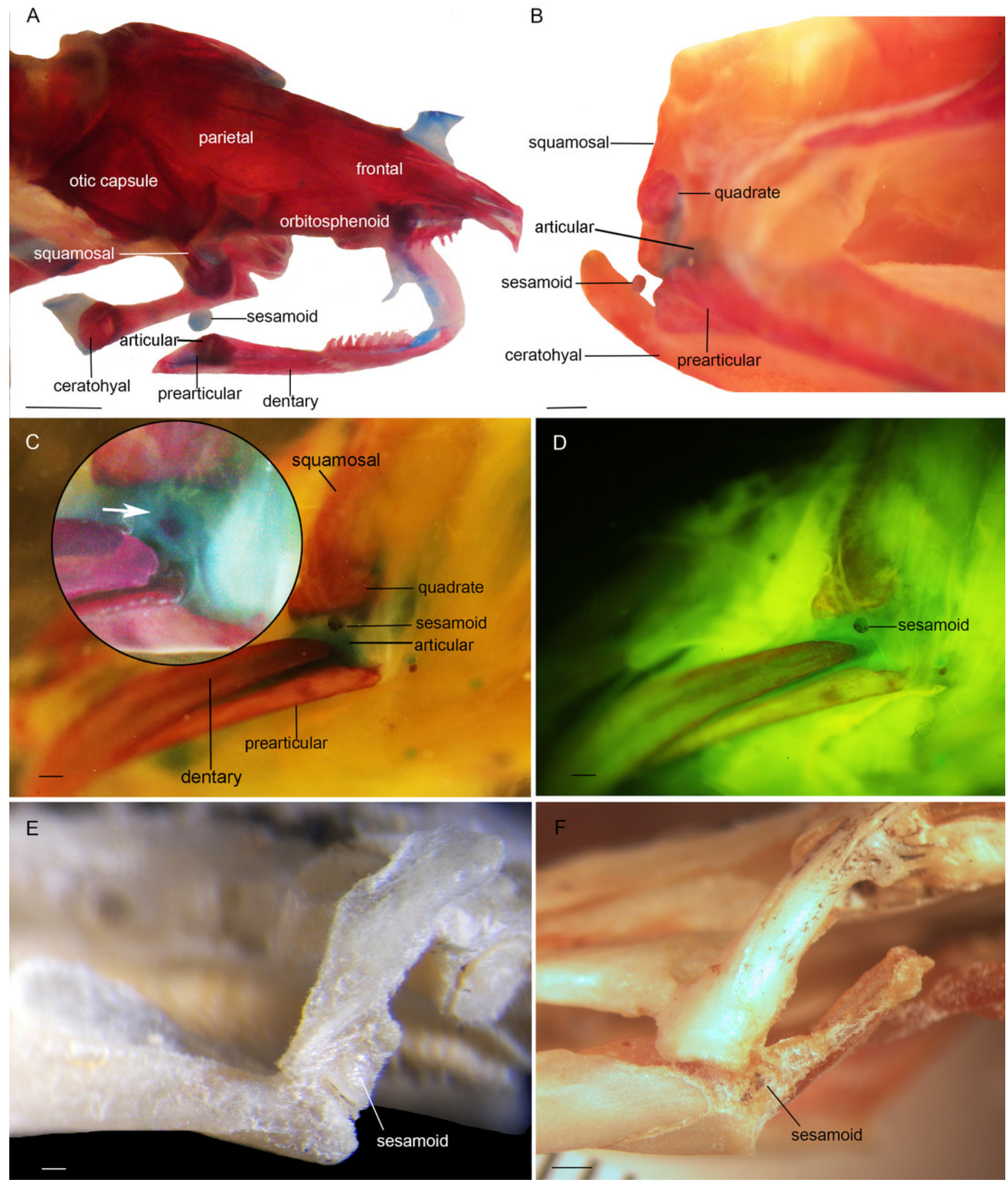


\section{Figure 3}

Mandibular sesamoid in the quadrate-prearticular joint of the skull of Notophthalmus viridiscens (FMNH93537) (A), Notophthalmus meridionalis (FMNH93536) under white (B) and fluorescent light (photo credit: Jennifer Y. Lamb) (C, D). Scale bar =

Mandibular sesamoid in the quadrate-prearticular joint of the skull of Notophthalmus viridiscens (FMNH93537) (A), Notophthalmus meridionalis (FMNH93536) under white (B) and fluorescent light (photo credit: Jennifer Y. Lamb) (C, D). Scale bar $=1 \mathrm{~mm}$.
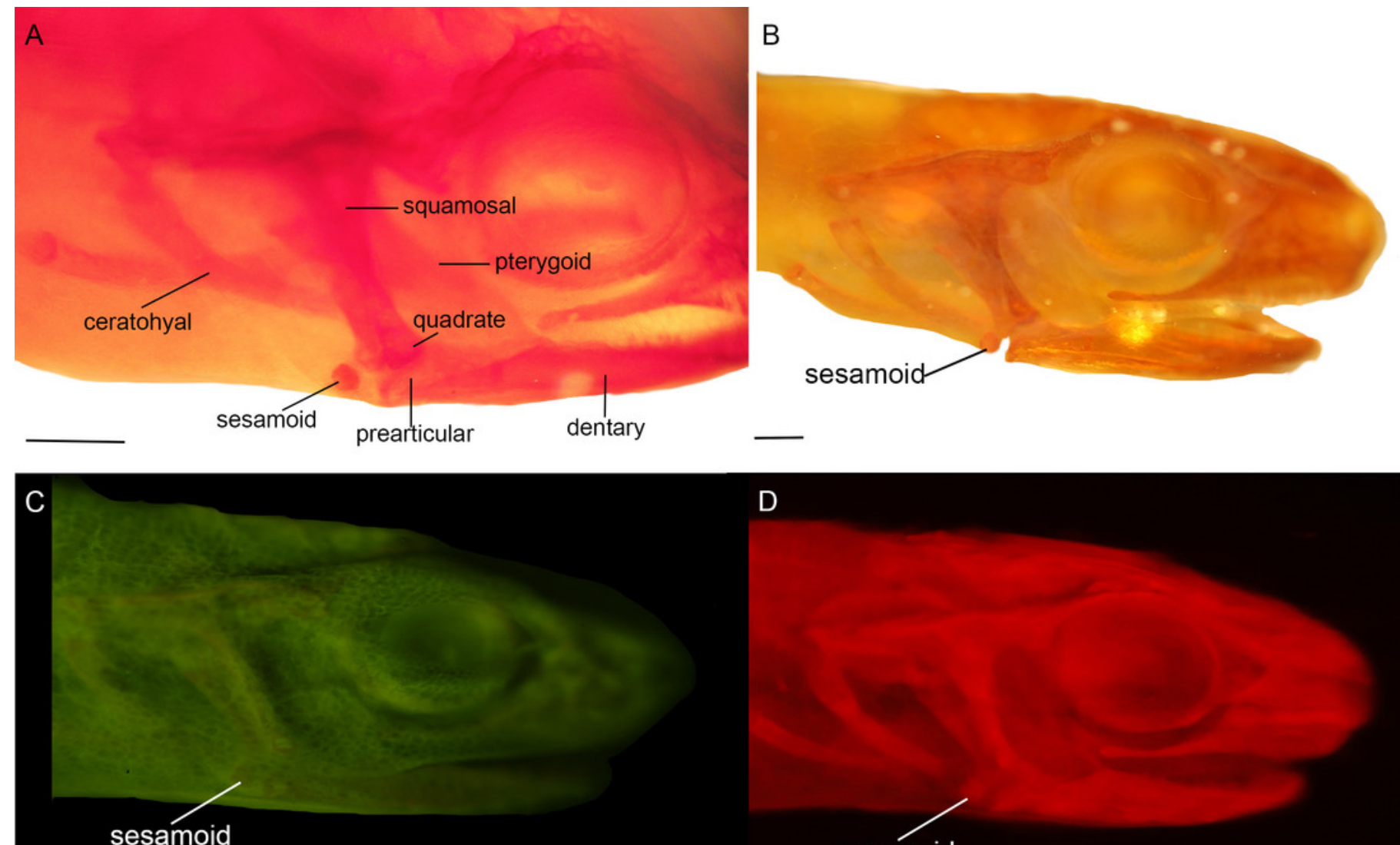

D 


\section{Figure 4}

Fig. 4. Accessory structure lateral to the terminal and subterminal phalanx of hands in Ambystoma mexicanum (FMNH22888) (A), and surrounding the skull of Ichthyophis bannanicus (MVZ236728) image credit: Digimorph.org (B).

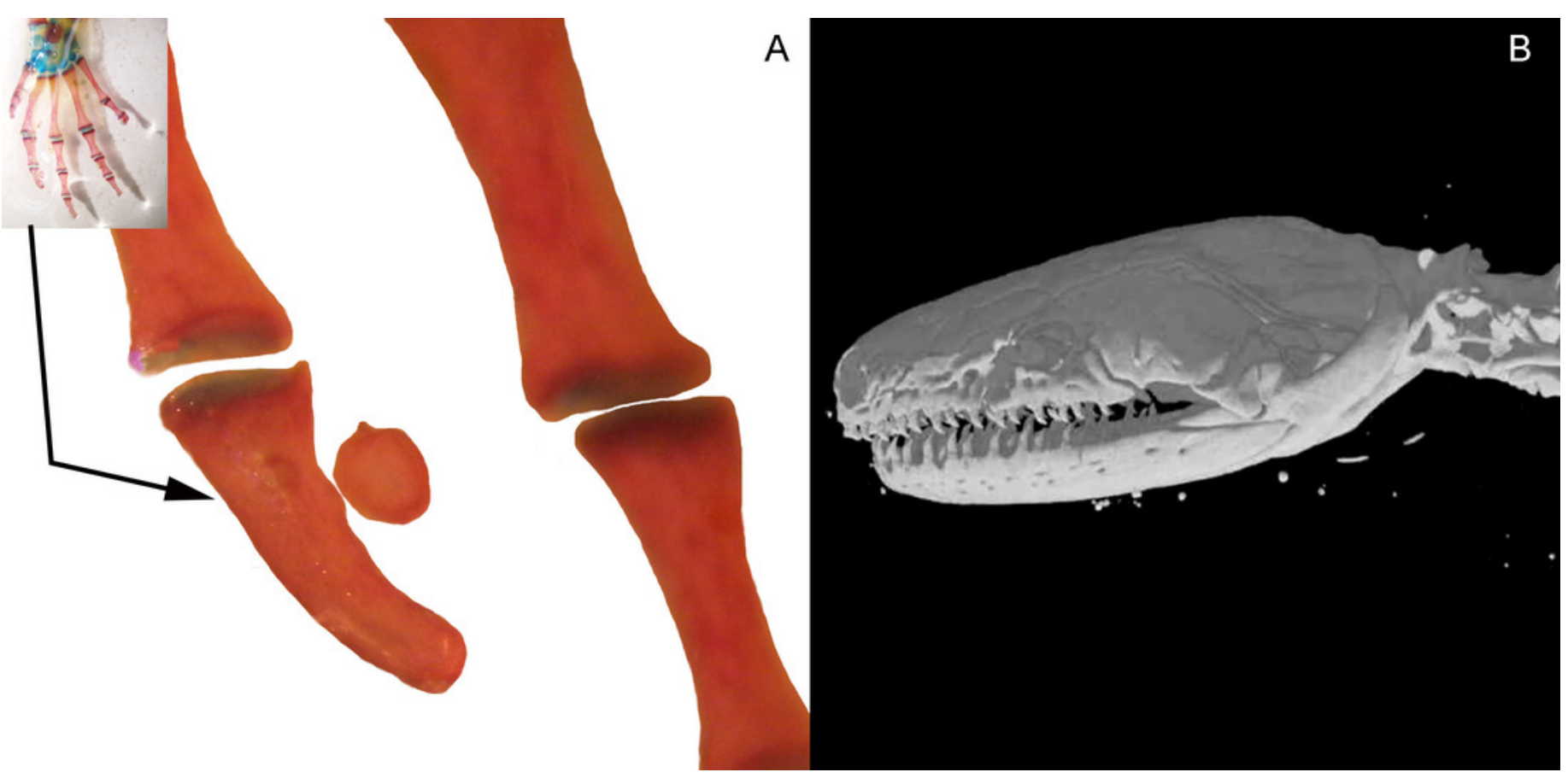




\section{Figure 5}

Salamander phylogeny used in the optimization analysis of mandibular sesamoid character follows relationships proposed by Bonnet \& Blair (2017) and Pyron \& Wiens (2011) for species not included in the most recent phylogeny.

Salamander phylogeny used in the optimization analysis of mandibular sesamoid character follows relationships proposed by Bonnet \& Blair (2017) and Pyron \& Wiens (2011) for species not included in the most recent phylogeny. Mapping of sesamoid of the mandibular symphysis is indicated in green; mapping of mandibular sesamoid, located between the quadrate and prearticular bone is indicated in red; mapping of sesamoid between the skull and the lower jaw, located at the posterior end of the maxilla is indicated in blue. 


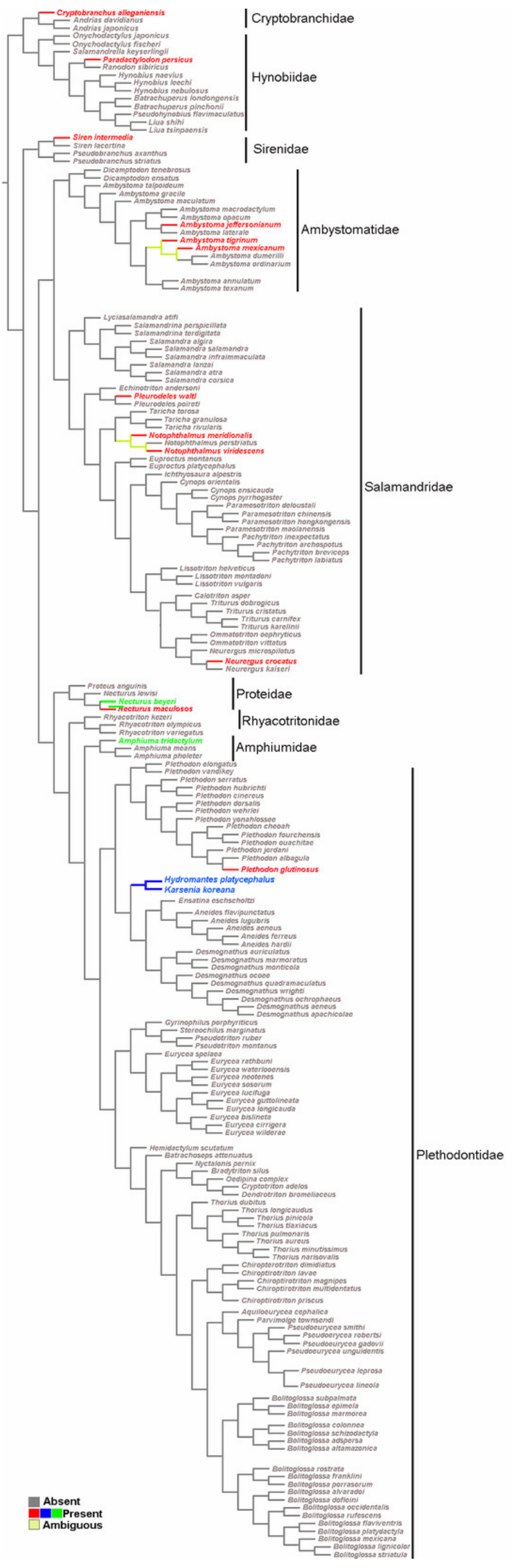

Peer) reviewing PDF | (2020:06:50216:3:0:NEW 22 Nov 2020) 


\section{Figure 6}

Examples of joints in salamanders and frogs showing the difference in the complexity of the joint surfaces.

(A) Manus of the facultative paedomorphic species Pleurodeles waltl (FML30803) (B) Manus of the paedomorphic species Siren intermedia (FMNH84082) (C) Manus of the anuran species Leptodactylus latinasus (FML S/N), showing the glide sesamoids in the inter-phalangeal joints. (D) Hindlimb of Pleurodeles waltl (FML30803), the simple articular surfaces of the knee and ankle joints are evident. (E) Ankle and (F) Knee joints of Leptodactylus bufonius (FML S/N) where the related sesamoids are visible. Scale bar $=1 \mathrm{~mm}$. 

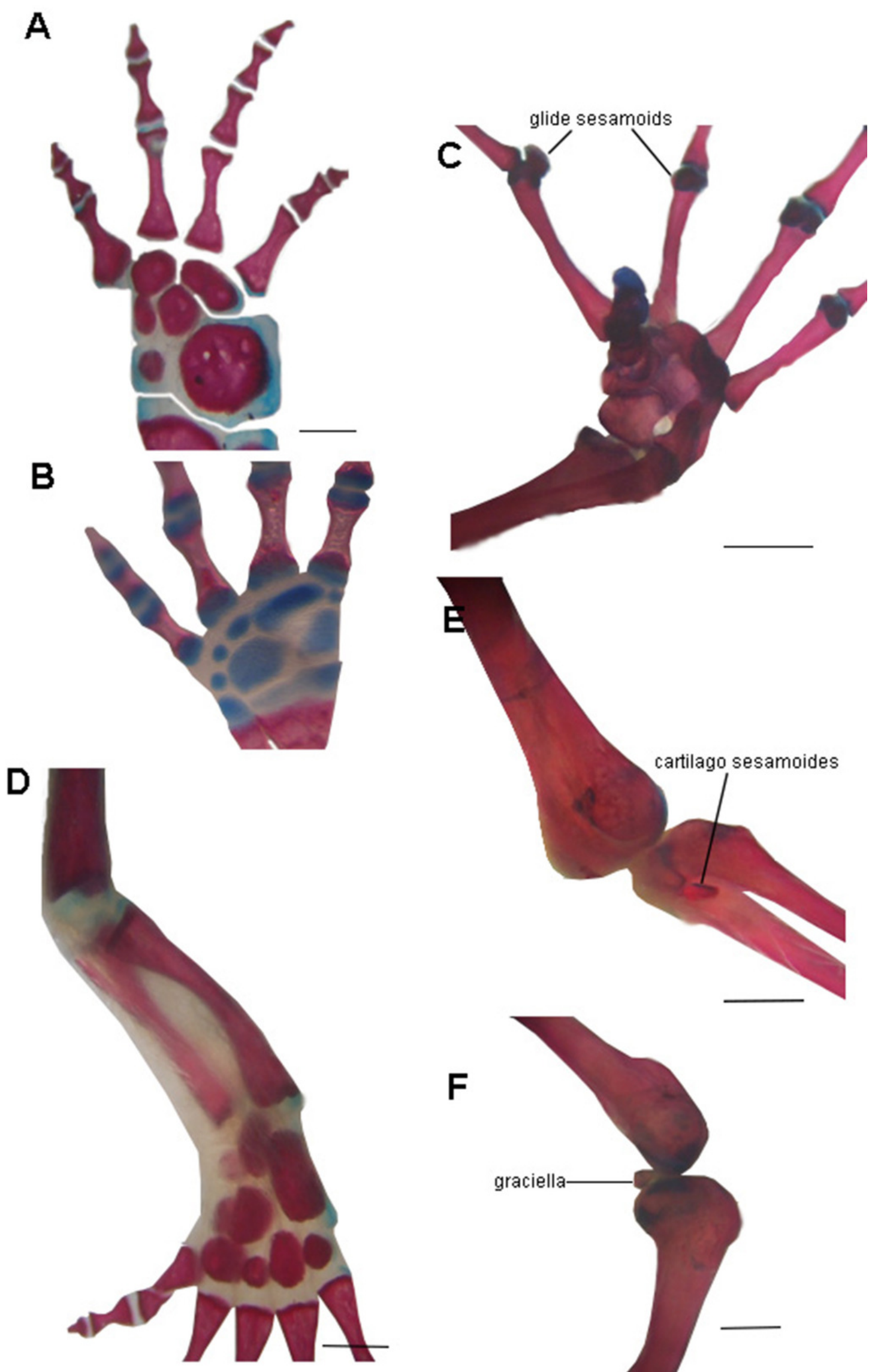

$\mathbf{F}$

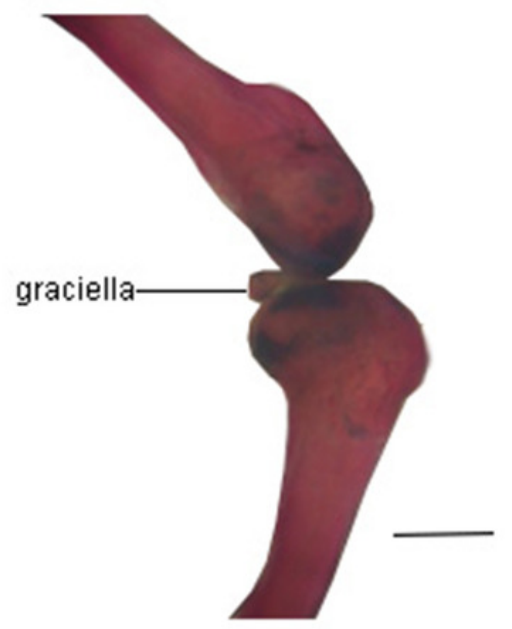




\section{Figure 7}

The three discussed hypotheses of interrelationships of the three modern amphibian groups and their relationships to possible Paleozoic records.

(A) Polyphyly hypothesis simplified from Ruta \& Coates (2007); (B) temnospondyl hypothesis (Trueb \& Clouthier, 1991; Milner, 1993; Ruta et al., 2003); (C) lepospondyl hypothesis (Laurin \& Reisz, 1997; Laurin, 1998; Vallin \& Laurin, 2004). Red bars indicate the presence of postcranial sesamoids (PS) as has been known until present. 
A

A Stem tetrapods

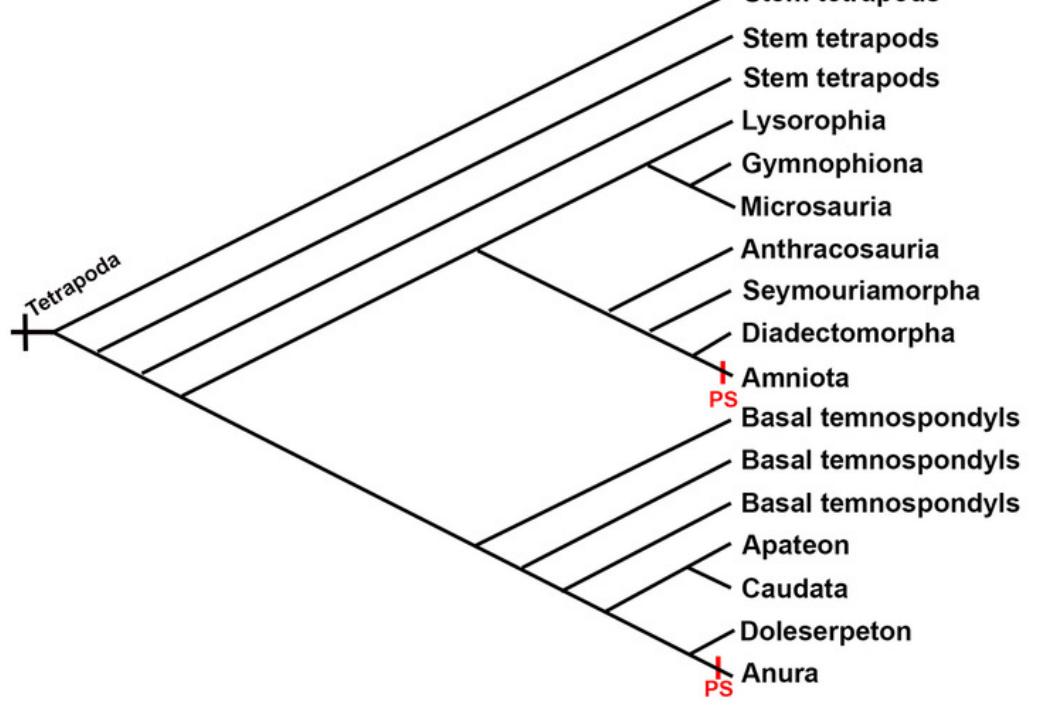

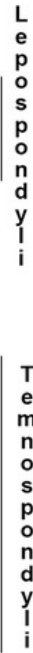

B
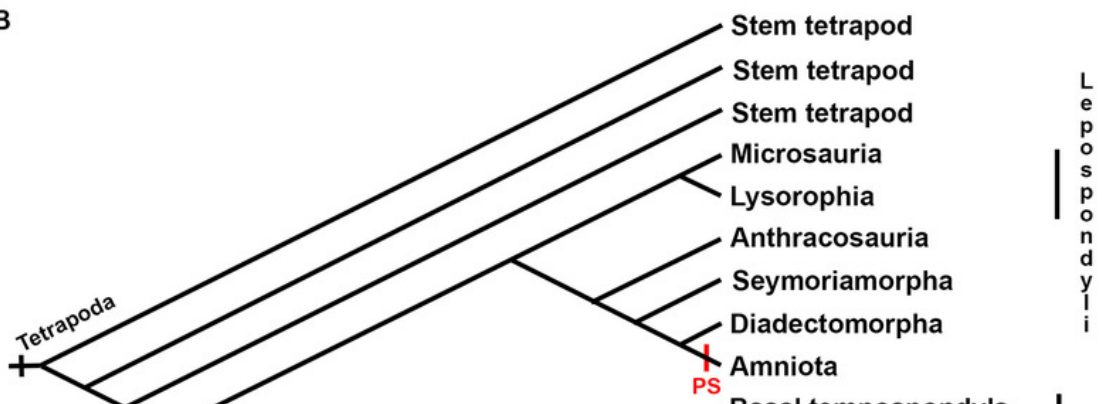

Basal temnospondyls

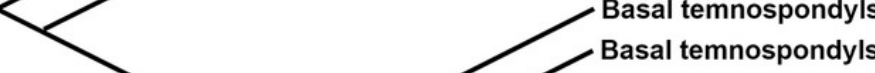

Basal temnospondyls

Doleserpeton

Apateon

Gymnophiona

Caudata

PS Anura

\begin{tabular}{|l}
$\mathrm{T}$ \\
e \\
$\mathrm{m}$ \\
$\mathrm{n}$ \\
$\mathrm{o}$ \\
$\mathbf{s}$ \\
$\mathrm{p}$ \\
$o$ \\
$n$ \\
$\mathrm{~d}$ \\
$\mathrm{y}$ \\
1 \\
$\mathrm{i}$
\end{tabular}

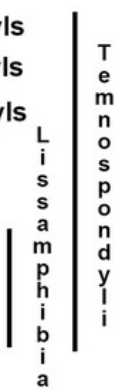

C

Stem tetrapod

Stem tetrapod

Stem tetrapod

Doleserpeton

Apateon

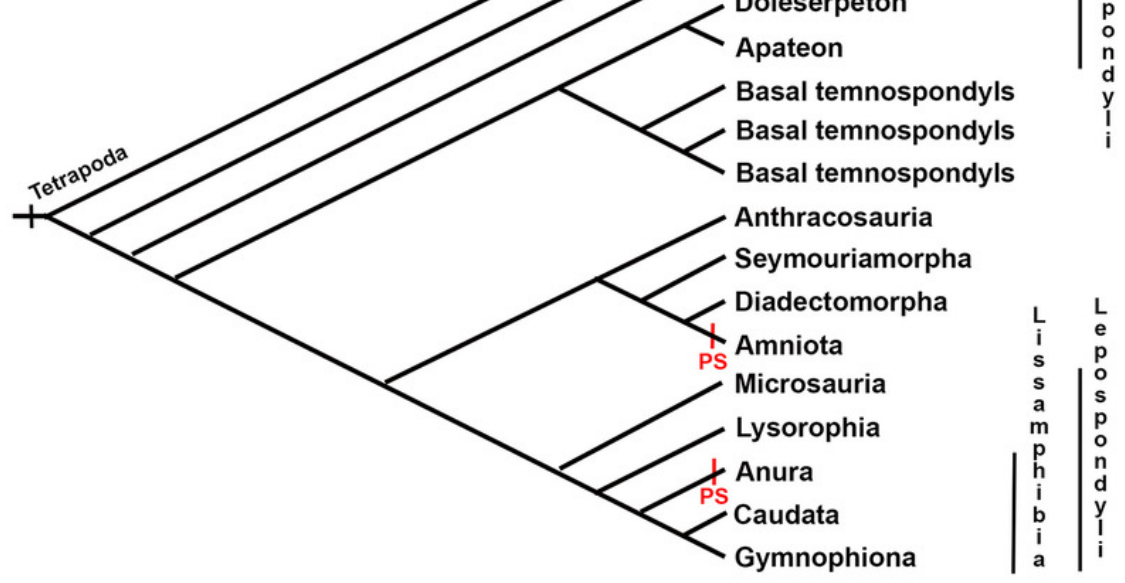

Peer] reviewing PDF | (2020:06:50216:3:0:NEW 22 Nov 2020) 


\section{Table $\mathbf{1}$ (on next page)}

Comparison of probabilities of occurrence of bony or cartilaginous sesamoids considering the described extant species to date in Caudata and Gymnophiona. *Data were taken from Frost (2020) 
1 Table 1: Comparison of probabilities of occurrence of bony or cartilaginous sesamoids considering the

2 described extant species to date in Caudata and Gymnophiona. *Data were taken from Frost (2020)

\begin{tabular}{|c|c|c|c|c|c|c|c|}
\hline & \multirow[t]{2}{*}{$\begin{array}{c}\text { Species } \\
\text { described }\end{array}$} & \multicolumn{2}{|c|}{ Species reviewed } & \multicolumn{2}{|c|}{$\begin{array}{l}\text { Species with } \\
\text { sesamoids }\end{array}$} & \multicolumn{2}{|c|}{$\begin{array}{c}\text { Probability of } \\
\text { occurrence }\end{array}$} \\
\hline & & Skull & Poscranium & Skull & Poscranium & Skull & Poscranium \\
\hline Caudata & $757^{*}$ & 200 & 147 & 16 & 0 & $2 \%$ & $0 \%$ \\
\hline Gymnophiona & $214 *$ & & 42 & 0 & 0 & $0 \%$ & $0 \%$ \\
\hline
\end{tabular}

3 